\title{
ANALISIS MAKNA METAFORA DALAM LIRIK LAGU “IGNITE”
}

\author{
R.Marthatiana ${ }^{1}$,P.D.W.Pratiwi ${ }^{2}$, I.W.Hastuti ${ }^{3}$ \\ ${ }^{123}$ Jurusan Bahasa Asing, Universitas Pendidikan Ganesha, Singaraja \\ e-mail : tiamarthatiana18@gmail.com, indahwidya06@gmail.com, \\ dewiwigantari18@gmail.com
}

\begin{abstract}
Abstrak
Artikel ini membahas makna metafora yang terkandung dalam lirik lagu berbahasa Jepang. Dengan menggunakan teori analisis metafora "Knowless and Moon (2006)", akan menganalisis larik yang mengandung makna metafora dari lirik lagu Ignite yang dipopulerkan oleh Aoi Eir. Tujuan dari penelitian ini adalah menggambarkan penggunaan dan makna metafora yang digunakan oleh penulis lagu. Lirik lagu dalam artikel ini dilihat sebagai bentuk puitika. Knowless dan Moon (2006: 7) mengidentifikasi dan menganalisis tiga komponen: (1) metaforanya; (2) maknanya; dan (3) kemiripan atau kaitan antara keduanya. Dalam pendekatan tradisional, ketiga komponen ini disebut vehicle, topic, dan grounds. Knowless dan Moon membedakan metafora menjadi dua jenis, yakni metafora kreatif dan konvensional. Larik-larik pada lirik lagu Ignite memuat metafora yang diciptakan secara kreatif oleh penulis lirik lagu, dan pendengar berusaha untuk menginterpretasikannya. Hasil penelitian ini menunjukan larik-larik pada lagu Ignite memiliki makna tentang keinginan suatu perasaan yang lemah dan ingin mengubahnya menjadi kuat dan bersinergi.
\end{abstract}

Kata Kunci: Metafora, Aoi Eir, Knowless and Moon, Lirik Lagu

\begin{abstract}
This article discusses the metaphorical meaning contained in Japanese song lyrics. Using the theory of metaphor analysis "Knowless and Moon (2006)", this analysis analyzes a few words from a data source titled Ignite popularized by Aoi Eir. The purpose of this study is to describe the use and meaning of metaphors used by song writers. Where the song's lyrics are like poetry. Theory of Moon and Knowless (2006: 7) namely by identifying and analyzing three components: (1) the metaphor; (2) its meaning; and (3) similarity or relationship between the two. In the traditional approach, these three components are called vehicle, topic, and grounds. Knowless and Moon distinguishes metaphors into two types, namely creative and conventional metaphors. Creative metaphors are metaphors that are usually used to express feelings, ideas or feelings into a writing or speech and make the speech partner must deconstruct the meaning in question. Usually this metaphor is used in literary works or advertisements. The results of this study indicate the lines in ignite have meaning about the desire of a weak feeling and want to change it to be strong and synergize.
\end{abstract}

Keywords: Metaphor, Aoi Eir, Knowless and Moon, Song Lyrics

\section{Pendahuluan}

Lirik lagu merupakan ekspresi seseorang tentang suatu hal yang sudah dilihat, didengar maupun yang dialaminya. Dalam mengekspresikan pengalamannnya, penyair atau pencipta lagu melakukan permainan kata-kata dan bahasa untuk menciptakan daya tarik dan keunikan terhadap lirik atau syairnya. Lirik lagu biasanya memiliki makna tersembunyi dan pastinya memiliki majas di dalam lirik yang ditulis oleh si pencipta.

Majas yaitu cara mengungkapkan pikiran melalui bahasa yang khas yang memperlihatkan jiwa dan kepribadian penulis. Sebuah majas yang baik harus mengandung unsur kejujuran, sopan-santun dan menarik (Keraf, 2010: 113 ). Dari sekian banyak jenis majas dan pengelompokannya, salah satu majas yang banyak dipergunakan adalah majas perbandingan. Salah satu diantara jenis majas perbandingan. Metafora termasuk ke dalam salah satu jenis majas perbandingan.

Metafora merupakan semua bentuk kiasan dan biasanya bahasa yang digunakan merupakan bahasa yang dianggap menyimpang dari bahasa baku (Ratna,2009:181). Wahab 
(1986:88-89) mengartikan metafora sebagai ungkapan kebahasaan yang tidak dapat diartikan secara langsung dari lambang yang dipakai, melainkan dari predikasi yang dapat dipakai baik oleh lambang maupun dari makna yang dimaksudkan oleh ungkapan bahasa itu. Wahab (1986) kemudian membagi metafora menjadi tiga bentuk, yaitu metafora nominatif, metafora predikatif dan metafora Dari semua majas yang ada, metafora merupakan majas yang paling sering muncul dan dimanfaatkan dalam sebuah karya sastra. Struktur metafora sangat sederhana, yaitu ada sesuatu yang dibicarakan, dan ada sesuatu sebagai pembanding. Metafora adalah sebagai ungkapan pembanding langsung, tidak mempergunakan pembanding: seperti, bak, bagaikan, dan sebagainya (Keraf 2002:139).

Menurut Knowless dan Moon (2006) membedakan metafora menjadi dua jenis, yakni metafora kreatif dan konvensional. Metafora kreatif adalah metafora yang biasanya digunakan untuk mengungkapkan perasaan, ide atau pikiran tertentu dalam konteks tertentu juga dan membuat mitra tuturnya harus mendekonstruksi makna yang dimaksud. Biasanya metafora ini digunakan dalam karya sastra atau iklaniklan. Sementara metafora konvensional adalah metafora yang sudah kerap digunakan oleh masyarakat.

Knowless dan Moon juga memerinci tipe metafora ke dalam bentuk berikut ini:

1. Personifikasi 'memperlakukan benda seolah-olah mempunyai sifat seperti manusia';

2. Simile 'perbandingan secara eksplisit antara sesuatu dengan yang lainnya';

3. Metonimi 'mengasosiasikan suatu bagian untuk mewakili keseluruhannya';

4. Sinestesia, yaitu perumpaan yang didasarkan pada citra penglihatan, pendengaran (bunyi), sentuhan, dan rasa.

Lagu berjudul Ignite dari Aoi Eir ada unsur metafora dalam lirik nya. Dalam lirik lagu metafora digunakan sebagai warna serta interpretasi baru. Metafora dianggap dapat menghiasi sebuah ungkapan agar terkesan lebih indah. Penulis akan membahas penggunaan metafora dalam lagu Ignite yang dipopulerkan oleh Aoi Eir.

\section{Metode}

Pada tahap pengumpulan data menggunakan teknik simak catat. Dengan cara menyimak larik-larik dari lirik lagu Ignite. Kemudian mencatat tanda-tanda yang ditemuka. Metode yang digunakan dalam menganalisis lagu ini adalah metode deskriptif yang menggambarkan metafora dalam lirik lagu Ignite karya Aoi Eir. Sumber data penelitian ini adalah lagu Ignite Karya Aoi Eir. Teori yang digunakan dalam menganalisis data adalah teori metafora yang dikemukakan oleh Moon dan Knowless.

\section{Hasil dan Pembahasan}

Dari analisis yang dilakukan, hasil yang ditemukan adalah hanya ditemukan dua tipe majas metafora yaitu Personifikasi dan Sinestesia. Kemudian akan dibahas mengenai makna metafora secara keseluruhan dari lagu Ignite. Berikut pembahasannya.

\section{Lirik kesatu}

\begin{tabular}{|c|c|}
\hline Lirik & $\begin{array}{l}\text { : 迷わずに今、矛盾だらけの世界をその手で撃ち放て。 } \\
\text { (Mayowazu ni ima mujun darake no sekai wo sono te de uchi hanate.) }\end{array}$ \\
\hline Metafora & $\begin{array}{l}\text { : "Mujun" } \\
\text { (kontradiksi) }\end{array}$ \\
\hline Makna & : Tantangan \\
\hline Koneksi & $\begin{array}{l}\text { : Pada bait lirik ini jelas dinyatakan bahwa seperti hadapi dunia yang penuh } \\
\text { tantangan atau pro kontra ini tanpa ragu, dunia diibaratkan sebagai sebuah } \\
\text { perlawanan atau perselisihan dan その手で -sono te de- "dengan tangan itu". Poin }\end{array}$ \\
\hline
\end{tabular}


yang dimaksud yaitu "tangan" merupakan bagian anggota tubuh yang dimiliki manusia, jadi maknanya dari tangan ini adalah hadapi apapun dengan tangan sendiri, dengan diri sendiri. Lirik lagu pada ini termasuk dalam majas personifikasi.

\section{Lirik kedua}

\begin{tabular}{|l|l|}
\hline Lirik & $\begin{array}{l}\text { : 憎しみを生み出していくんだろう。 } \\
\text { (Nikushimi wo umi dashite yuku ndarou.) }\end{array}$ \\
\hline Metafora & $\begin{array}{l}\text { : “Umi” } \\
\text { (terlahir) }\end{array}$ \\
\hline Makna & : Memunculkan, menimbulkan \\
\hline Koneksi & $\begin{array}{l}\text { : Makna "terlahir" pada bait lirik lagu ini yang merupakan melahirkan sebuah } \\
\text { kebencian, yaitu kebencian itu muncul atau timbul karena suatu hal. Lirik lagu pada } \\
\text { ini termasuk dalam majas personifikasi. }\end{array}$ \\
\hline
\end{tabular}

\section{Lirik ketiga}

\begin{tabular}{|c|c|}
\hline Lirik & $\begin{array}{l}\text { : 赤い涙で覆われた悲しみをそっとそっと抱きしめて。 } \\
\text { ( } \text { (Akai namida de oowareta kanashimi wo sotto sotto dakishimete.) }\end{array}$ \\
\hline Metafora & $\begin{array}{l}\text { : "Akai namida” } \\
\text { (air mata merah) }\end{array}$ \\
\hline Makna & : Mengartikan kemarahan yang sedang tersembunyi \\
\hline Koneksi & $\begin{array}{l}\text { : Dalam kehidupan sering kali kita merasakan kesedihan yang amat mendalam, } \\
\text { namun tak bisa di pungkiri terkadang air mata juga bisa disembunyikan di balik } \\
\text { kemarahan. Dalam lagu ini maksud pengarang hanya air mata yang melukiskan } \\
\text { kesedihan namun merah melambangkan kemarahan. Lirik lagu pada ini termasuk } \\
\text { dalam majas sinestesia. }\end{array}$ \\
\hline
\end{tabular}

\section{Lirik keempat}

\begin{tabular}{|l|l|}
\hline Lirik & $\begin{array}{l}\text { : 振り絞った感情が静寂の闇を切り裂くように。 } \\
\text { (Furishibotta kanjou ga seijaku no yami wo kirisaku youni.) }\end{array}$ \\
\hline Metafora & $\begin{array}{l}\text { : “Kirisaku” } \\
\text { (Memotong) }\end{array}$ \\
\hline Makna & : Menghilangkan, melenyapkan \\
\hline Koneksi & $\begin{array}{l}\text { : Konteks memotong pada lirik ini seperti merobek keheningan atau kesunyian. Poin } \\
\text { yang dimaksud adalah seperti menghilangan atau melenyapkan suasana hening } \\
\text { atau sunyi ketika pada malam hari. Lirik lagu pada ini termasuk dalam majas } \\
\text { personifikasi. }\end{array}$ \\
\hline
\end{tabular}




\section{Lirik kelima}

\begin{tabular}{|c|c|}
\hline Lirik & $\begin{array}{l}\text { : こぼれた 涙の温もりで優しさを知ったはずなのに。 } \\
\text { (Koboreta namida no nukumori de yasashisa o shitta hazu na no ni.) }\end{array}$ \\
\hline Metafora & $\begin{array}{l}\text { : "Nukumori" } \\
\text { (kehangatan) }\end{array}$ \\
\hline Makna & : Perasaan \\
\hline Koneksi & $\begin{array}{l}\text { : Kehangatan termasuk dalam perihal dalam keadaan rasa senang, sedih atau suka } \\
\text { cita. Tentu saja arti tersebut dapat dimaknakan berkaitan dengan suasana hati. } \\
\text { Pada arti lirik lagu ini, kehangatan yang menandakan suasana hati yang sedih } \\
\text { karena diikuti dengan air mata. Lirik lagu ini termasuk dalam majas sinestesia. }\end{array}$ \\
\hline
\end{tabular}

\section{Lirik keenam}

\begin{tabular}{|l|l|}
\hline Lirik & $\begin{array}{l}\text { : 世界は生まれ変わる夜空の幕開けを見たなら。 } \\
\text { (Sekai wa umarekawaru yozora no makuake wo mitanara.) }\end{array}$ \\
\hline Metafora & $\begin{array}{l}\text { : “Umarekawaru” } \\
\text { (terlahir kembali) }\end{array}$ \\
\hline Makna & : Baru \\
\hline Koneksi & $\begin{array}{l}\text { : Seperti yang diketahui, makna dari terlahir kembali adalah sesuatu hal yang baru, } \\
\text { awal yang baru, memulai hidup secara baru. Dalam lirik lagu ini yang dimaksudkan } \\
\text { terlahir kembali adalah dunia, akan ada kehidupan baru di dunia setelahnya. Lirik } \\
\text { lagu pada ini termasuk dalam majas personifikasi. }\end{array}$ \\
\hline
\end{tabular}

\section{Lirik ketujuh}

\begin{tabular}{|l|l|}
\hline Lirik & $\begin{array}{l}\text { : 明日を信じて錆び付いていたままの屝を打ち破れ。 } \\
\text { (Asu o shinjite sabitsuite ita mama no tobira o uchiyabure.) }\end{array}$ \\
\hline Metafora & $\begin{array}{l}\text { : "Sabitsui" } \\
\text { (berkarat) }\end{array}$ \\
\hline Makna & $:$ (Hal) yang sudah lama \\
\hline Koneksi & $\begin{array}{l}\text { : Berkarat seperti halnya benda yang berbentuk logam yang sudah tidak terpakai } \\
\text { lagi dalam jangka yang waktu yang begitu lama. jika dalam lirik lagu ini yang } \\
\text { dimaksudkan berkarat adalah sebuah pintu yang sudah tertutup. Pada lirik ini } \\
\text { memiliki arti bahwa untuk menghancurkan pintu yang sudah berkarat atau sama } \\
\text { halnya mimpi yang sudah lama terpendam dan mempercayai bahwa hari esok akan } \\
\text { lebih baik dari sebelumnya. Lirik lagu pada ini termasuk dalam majas sinestesia. }\end{array}$ \\
\hline
\end{tabular}

Dari hasil analisis pada lirik lagu Aoi Eir yang berjudul Ignite ditemukan dua jenis metafora yaitu Personifikasi dan Sinestesia. Dari data yang dianalisis tidak ditemukan majas Simile dan Metonimi. Adapun dari 7 lirik yang dianalisis ditemukan 4 (empat) majas personifikasi dan 3 ( tiga ) majas sinestesia. Oleh karena itu, jenis metafora personifikasi paling banyak ditemukan dalam lirik lagu Aoi Eir yang berjudul Ignite. 


\section{KESIMPULAN}

Dari hasil analisis pada lirik lagu Aoi Eir yang berjudul Ignite ditemukan dua jenis metafora yaitu Personifikasi dan Sinestesia. Dari data yang dianalisis tidak ditemukan majas Simile dan Metonimi. Adapun dari 7 lirik yang dianalisis ditemukan 4 (empat) majas personifikasi dan 3 ( tiga ) majas sinestesia. Oleh karena itu, jenis metafora personifikasi paling banyak ditemukan dalam lirik lagu Aoi Eir yang berjudul Ignite. Lagu ini menggunakan metafora untuk memperlihatkan suatu perasaan yang lemah berubah menjadi kuat. Hal ini terlihat pada kata-kata sekarang tanpa ragu bidiklah dunia yang penuh dengan kontradiksi ini dan tariklah pelatuknya dengan tangan itu.

\section{DAFTAR PUSTAKA}

Aminuddin. 2001.Semantik: Pengantar Studi tentang Makna. Bandung: Sinar Baru Algesindo Knowles, M., and Moon, R. 2006. Introducing Metaphor. New York: Routledge.

Lakoff, G., \& Johnson, M. 1980. Metaphor We Live. London: The University of Chicago Press.

Mulia,dkk. 2016. Metafora メタファー dalam lirik lagu Jepang yang dipopulerkan oleh Utada Hikaru. (Vol 2 no 3).

Puspita, D dan Irma, W. 2018. Metafora pada Lirik Lagu AKB48. Semarang: Universitas Dian Nuswantoro.

Saifudin, Akhmad. 2012. Metafora Dalam Lirik Lagu Kokoro no Tomo Karya Itsuwa Mayumi. Lite: Jurnal Bahasa, Sastra dan Budaya, Vol. 8, No. 2. Udinus: Semarang

Sumawijaya, Bambang. 2008. Teori-teori Semiotika, Sebuah Pengantar. http://bambangsukmawijaya.wordpress.com/2008/02/19/teori-teori-semiotika-sebuahpengantar/ (diunduh pada tanggal 22 september 2012)

Sumolang, O.G. 2015. Metafora Dalam Lirik Lagu Karya Adele. Skripsi: Universitas Sam Ratulangi (tidak diterbitkan). 